\title{
TREND OF WATER QUALITY STATUS IN KELANTAN RIVER DOWNSTREAM, PENINSULAR MALAYSIA
}

\author{
ARNIZA FITRI ${ }^{{ }^{*}}$, KHAIRUL NIZAM ABDUL MAULUD ${ }^{2,3}$, DIAN PRATIWI ${ }^{1}$, \\ ARLINA PHELIA ${ }^{1}$, FARLI ROSSI ${ }^{4}$, NUR ZUKRINA ZUHAIRI ${ }^{3}$ \\ ${ }^{1}$ Department of Civil Engineering, Faculty of Engineering and Computer Science, Universitas Teknokrat Indonesia, Bandar \\ Lampung, Indonesia \\ ${ }^{2}$ Department of Civil Engineering, Faculty of Engineering and Built Environment, Universiti Kebangsaan Malaysia, 43600 \\ Bangi, Selangor, Malaysia \\ ${ }^{3}$ Earth Observation Centre, Institute of Climate Change, Universiti Kebangsaan Malaysia, 43600 Bangi, Selangor, Malaysia \\ ${ }^{4}$ Department of Electrical Engineering, Faculty of Engineering and Computer Science, Universitas Teknokrat Indonesia, \\ Bandar Lampung, Indonesia \\ *Corresponding Author : \arniza@teknokrat.ac.id
}

Manuscript received : 28 September 2020. Accepted: 16 December 2020.

\begin{abstract}
The issues of freshwater pollutions and the high demand of clean freshwater for daily human activities have forced developing countries such as Malaysia to continuously monitor the quality of the freshwater. The present study objective is to present the trend of water quality status in the Kelantan River downstream, Peninsular Malaysia from 2005 to 2018. Water samples were collected during dry and monsoon seasons from a sampling station located at downstream of the Kelantan River. Water quality parameters such as temperature, $\mathrm{pH}$ and dissolved oxygen (DO) were measured in situ while other parameters were analysed in the laboratory based on retrieved water samples. Water quality status was determined based on National Water Quality Standard (NWQS) for River in Malaysia by calculating the water quality index (WQI) according to the concentration of six water quality parameters involving $\mathrm{pH}$, dissolved oxygen (DO), biochemical oxygen demand (BOD), chemical oxygen demand (COD), suspended solids (TSS) and Ammonia Nitrogen (AN). The results showed that Kelantan River had good water quality during the dry season classified in Class II at 2005. The water quality was found to be slightly lower during the monsoon season in year 2006. In addition, increasing the number of construction, human activities in the land use areas, land use changes and the sewage water from domestic, industrial, wet market and food outlets in the Kelantan State have declined the water quality in Kelantan River from Class II (in 2005) to Class III (in 2010 and 2011) and to become Class IV in 2017 to 2018. The results of the present study are expected to give valuable information for the water managers in order to deal with better strategies in controlling the quality of freshwater at the Kelantan River and minimize the incidence of pollution-oriented problems, thus the water can be utilized for various water uses with appropriate quality.
\end{abstract}

Keywords : Kelantan River, water quality status, WQI, water quality parameters 


\section{INTRODUCTION}

Great quality of freshwater is the most important for human existence in the world because it is extensively used for domestic, recreation, agriculture, fishing, drainage/irrigation and industrial purposes (Hee et al., 2019; Lai \& Fitri, 2011; Peck Yen \& Rohasliney, 2013; Varol, 2020). The issues of freshwater pollutions and the high demand of freshwater for daily human activities have forced developing countries such as Malaysia to continuously monitor the quality of the freshwater (Afroz et al., 2014; Department of Environment, 2014; Hee et al., 2019; Juahir et al., 2011; Kamarudin et al., 2019; Ma'arof \& Hua, 2015; Suratman et al., 2009; Wahab et al., 2019).

Kelantan River is the largest river in Peninsular Malaysia while Kelantan state is one of the developed regions in Malaysia. The Kelantan River plays a necessary role in supporting the economy of local people and government because it is extensively required for domestic use, agriculture, harvesting, industry etc. (Abdul Maulud, K. N. et al., 2020; Hee et al., 2019). Based on finding from spatial analyses, there were increasing of land use changes in the state of Kelantan from year 2012 to 2018 (Abdul Maulud, et al., 2020). Construction activities have increased from 3,031.4 Ha to 55,463.0 Ha (about 1,729 \% increment), cropland areas have increased from $404,760 \mathrm{Ha}$ to $496,385 \mathrm{Ha}$ (about $22 \%$ increment) and forest areas have decreased from 1,067,930 Ha to 912,045 Ha (about 14\% reduction) (Abdul Maulud, et al., 2020). Negative impacts from landuse changes on river water quality has been reviewed by Camara et al. (Camara et al., 2019). The increase of population and land use changes made the Kelantan River basin facing the growing pressures which may increase pollutions and water stress in future decades. It is therefore essential to take water quality monitoring to make sure that this valuable river retains clean. Besides, monitoring the status of water quality is becoming compulsory in order to provide the water managers with crucial information related to water resources management (Fulazzaky et al., 2010; Mokhtar et al., 2009).

This study attempted to present the trend of water quality status in the Kelantan River downstream, Peninsular Malaysia from year 2005 to year 2018. The status of water quality in Kelantan River was determined based on the National Water Quality Standard (NWQS) for River in Malaysia by calculating Water Quality Index (WQI). The WQI was calculated using six important water quality parameters including dissolved oxygen (DO), biochemical oxygen demand (BOD), chemical oxygen demand (COD), ammonia nitrogen (AN), $\mathrm{pH}$ and total suspended solid (TSS) (Amneera et al., 2013; Hee et al., 2019; Wu et al., 2018). The presented trend of water quality is expected to give valuable information for the water managers in order to deal with better strategies in controlling the quality of freshwater in Kelantan River and minimize the incidence of pollution-oriented problems, thus the water can be utilized for various water uses with appropriate quality.

\section{MATERIAL AND METHOD}

\subsection{Study Area and Water Sampling Point}

This study was carried out in the Kelantan River basin, east coast of Peninsular Malaysia laid approximately at latitude $5^{\circ} 00^{\prime} \mathrm{E}$ to $6^{\circ} 12^{\prime} \mathrm{E}$ and longitude $101^{\circ} 50^{\prime} \mathrm{N}$ to $102^{\circ} 20^{\prime} \mathrm{N}$. The station of water sampling was located at the most downstream of the Kelantan River with coordinate E $102^{\circ} 14^{\prime} 42.0^{\prime \prime}$ and N $6^{\circ} 10^{\prime} 19.3$ ". Figure 1 describes the study area and the location of the water sampling station. 
Kelantan River is influenced by two seasons per year that are dry season between April and September and the monsoon season between October and March. The heavy rainfall occurs during the monsoon season. The annual rainfall at Kelantan River basin is about $1700 \mathrm{~mm}$ or above.

\subsection{Water Sampling Procedure and Analyses}

In this study, water samples were collected at the sampling station for several occasion on August 2005 (dry season), January 2006 (monsoon season), August 2010 (dry season), January 2011 (monsoon season), August 2017 (dry season) and January 2018 (monsoon season). Water samples were collected using certain bottles according to the APHA method (APHA, 2017). PH and dissolved oxygen (DO) concentrations were recorded directly in situ by using YSI meter, while other parameters such as BOD, COD, TSS and AN were examined in the laboratory based on collected water samples according to the APHA method. BOD was determined by recording the DO values from the samples before and 5-day after its incubation at $20^{\circ} \mathrm{C}$. COD was examined using the method of open efflux (APHA, 2017). For TSS concentration, a $100 \mathrm{ml}$ water sample was filtered via a membrane filter, then it was dried in an oven at $105^{\circ} \mathrm{C}$ and finally, it was weighed. In addition, Ammonia Nitrogen was measured by using Nessler methods (HACH, 2007).

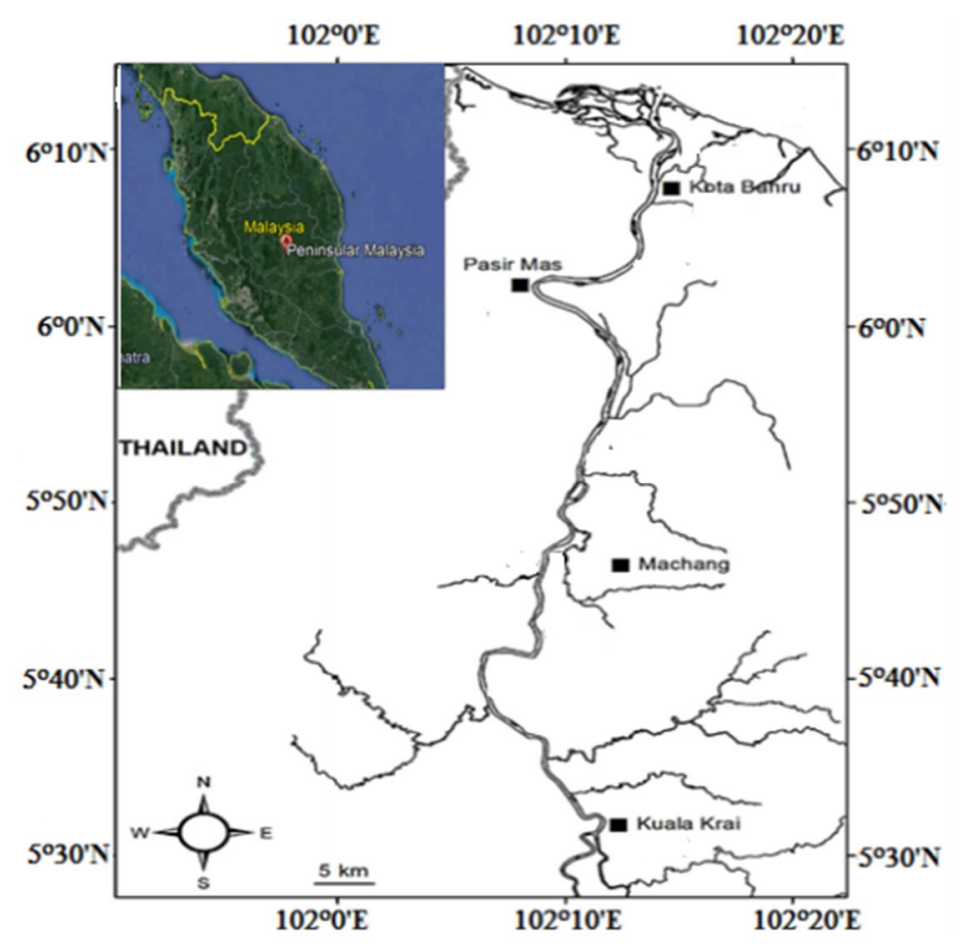

Figure 1. Location of The Study Area and Sampling Station

\subsection{Water Quality Index Based on NWQS, Malaysia}

Water quality index (WQI) allowed the identification of water quality status in a waterbody (Chapman, 1996; Hee et al., 2019) through calculating sub-indexes of six water quality parameters ( $\mathrm{pH}, \mathrm{DO}, \mathrm{BOD}, \mathrm{COD}, \mathrm{AN}, \mathrm{TSS})$ as provided under the National Water Quality 
Standard (NWQS) for River in Malaysia. Here, WQI was used to determine the status of water quality in Kelantan River downstream, Peninsular Malaysia.

\section{RESULTS AND DISCUSSION}

Figure 2 shows the mean values of six water quality parameters (pH, DO, BOD, COD, AN and TSS) at the downstream of Kelantan River, Peninsular Malaysia from year 2005 to 2018 sometimes at dry and monsoon seasons.

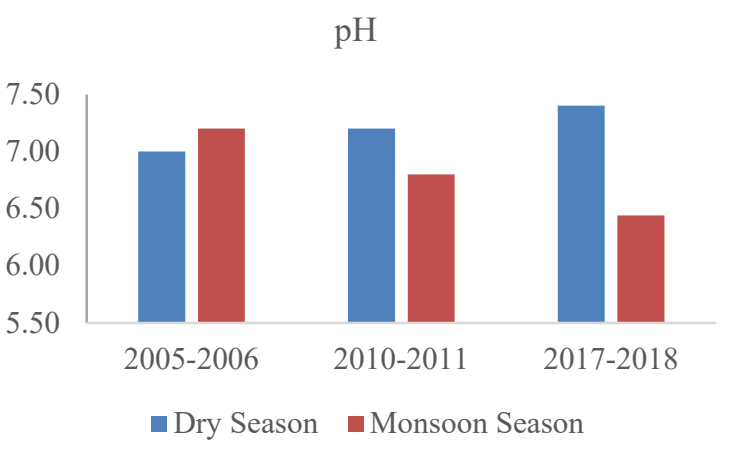

DO Concentration $(\mathrm{mg} / \mathrm{L})$

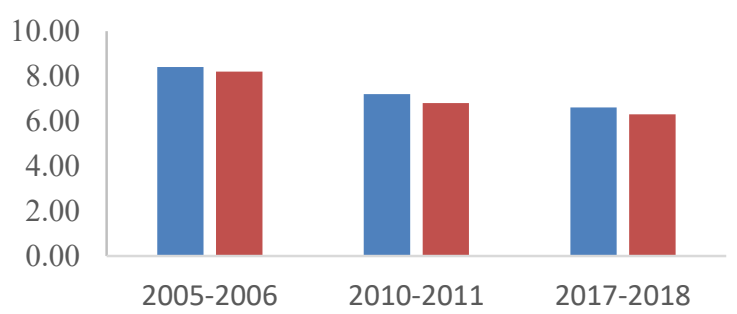

- Dry Season Monsoon Season

COD Concentration $(\mathrm{mg} / \mathrm{L})$

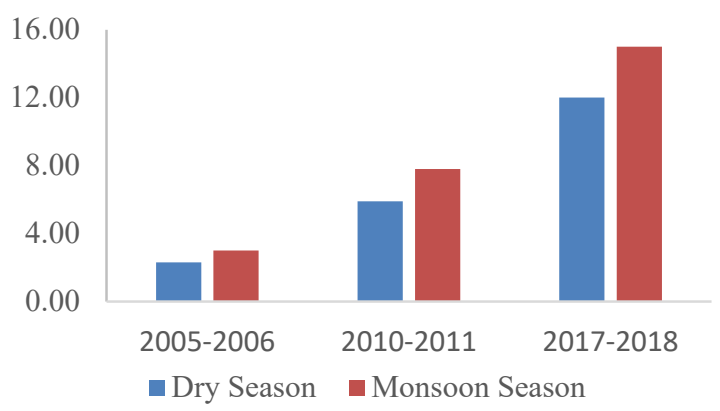

TSS Concentration $(\mathrm{mg} / \mathrm{L})$

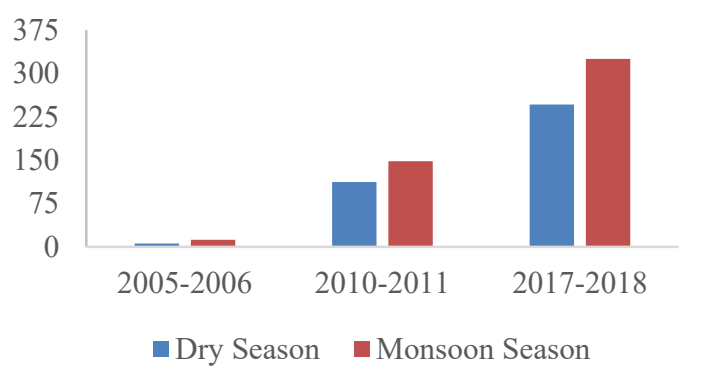

BOD Concentration $(\mathrm{mg} / \mathrm{L})$

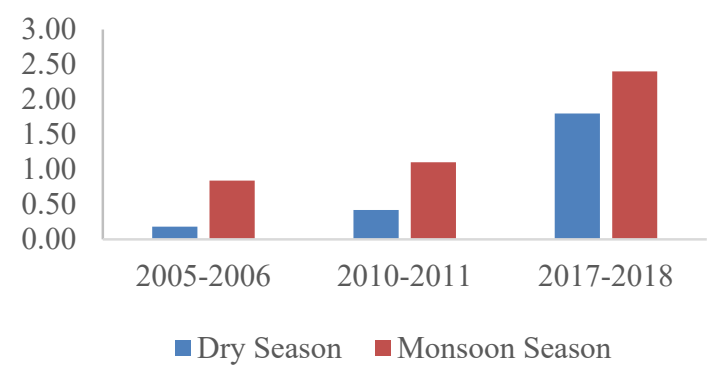

AN Concentration $(\mathrm{mg} / \mathrm{L})$

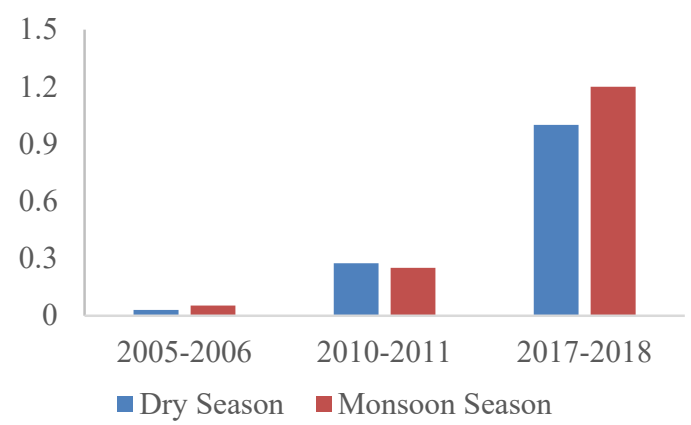

Figure 2. Mean Values of $\mathrm{pH}$, TSS, DO, BOD, COD and AN at downstream of Kelantan River

Based on Figure 2, the results illustrated that there were continually declining the dissolved oxygen concentration at downstream of the Kelantan River basin from year 2005 to 2018. Further, the concentrations of dissolved oxygen were recorded to be slightly reduced during the monsoon season compared to the dry season. In contrast, concentrations of TSS, COD, 
BOD and AN were recorded to be continually increased from year 2005 to 2018 with higher concentrations that were found during monsoon season. The results demonstrated that the increase of TSS, BOD, COD and AN had reduced the concentration of DO in the freshwater which was in line with results found by Ahmad et al., (Ahmad et al., 2009) and Hee et al., (Hee et al., 2019). During the dry season, the concentration of TSS, BOD, COD and AN were recorded about $5.6 \mathrm{mg} / \mathrm{L}, 0.18 \mathrm{mg} / \mathrm{L}, 2.3 \mathrm{mg} / \mathrm{L}$ and $0.03 \mathrm{mg} / \mathrm{L}$, respectively at the year 2005 while the concentration of TSS, BOD, COD and AN were recorded much higher at year 2017 which were about $246 \mathrm{mg} / \mathrm{L}, 1.8 \mathrm{mg} / \mathrm{L}, 12 \mathrm{mg} / \mathrm{L}$ and $1 \mathrm{mg} / \mathrm{L}$ respectively. During monsoon season, the concentration of TSS, BOD, COD and AN were recorded about $12 \mathrm{mg} / \mathrm{L}, 0.84$ $\mathrm{mg} / \mathrm{L}, 3 \mathrm{mg} / \mathrm{L}$ and $0.053 \mathrm{mg} / \mathrm{L}$ respectively at year 2006 while the concentration of TSS, BOD, COD and AN reached $325 \mathrm{mg} / \mathrm{L}, 2.4 \mathrm{mg} / \mathrm{L}, 15 \mathrm{mg} / \mathrm{L}$ and $1.2 \mathrm{mg} / \mathrm{L}$ respectively at year 2018.

Subindex values for six water quality parameters during dry and monsoon seasons from year 2005 to 2018 are presented in Table 1 . In addition, Table 1 also presents the status of water quality in downstream of the Kelantan River for each season from 2005 to 2018 based on the values of WQIs calculated from the subindex values.

Table 1. The values of subindex for six water quality parameters and WQI for each season from year 2005 to 2018

\begin{tabular}{llllllllll}
\hline \multirow{2}{*}{$\begin{array}{l}\text { Time } \\
\text { Period }\end{array}$} & \multirow{2}{*}{ Season } & \multicolumn{9}{l}{ Water Quality Parameter Subindex } & & \multirow{2}{*}{ WQI } & \multirow{2}{*}{ Class } \\
\cline { 3 - 10 } & & SIDO & SIBOD & SICOD & SIAN & SISS & SIpH & & \\
\hline \multirow{2}{*}{$2005-2006$} & Dry & 6.03 & 99.64 & 96.04 & 97.35 & 96.29 & 99.35 & 77.56 & II \\
\cline { 2 - 10 } & Monsoon & 4.27 & 96.85 & 95.11 & 94.94 & 90.50 & 98.65 & 76.04 & II \\
\hline \multirow{2}{*}{$2010-2011$} & Dry & 0.00 & 98.62 & 91.25 & 71.63 & 57.67 & 93.71 & 69.81 & III \\
\cline { 2 - 9 } & Monsoon & 0.00 & 95.75 & 88.73 & 74.25 & 53.81 & 83.63 & 62.79 & III \\
\hline \multirow{2}{*}{$2017-2018$} & Dry & 0.00 & 83.48 & 83.14 & 23.00 & 41.60 & 97.46 & 50.97 & IV \\
\cline { 2 - 8 } & Monsoon & 0.00 & 79.25 & 79.15 & 7.06 & 37.34 & 96.39 & 46.32 & IV \\
\hline
\end{tabular}

Based on Table 1, the results showed that the Kelantan River had good water quality during dry season at year 2005 which is classified in Class II. The river water was suitable for sensitive aquatic species and can be used for water supply with conventional treatment. However, the water quality was found to be slightly lower during monsoon season at 2006 due to the increase of TSS, BOD, COD and AN concentration.

In addition, the increase of land use changes and the number of development at Kelantan State from year 2012 to 2018 (in example, land use changes for cropland were increased about $22 \%$ while the number of constructions were increased about 1,729\%) (Abdul Maulud, et al., 2020)) as well as increasing the sewage water from domestic, industrial, wet market and food outlets in the Kelantan State have declined the water quality in Kelantan River downstream i.e water quality was declined from Class II (at year 2005) to be Class III (at year 2010 and 2011) and finally it was decreased again to become Class IV at 2017 to 2018. The results demonstrated that extensive treatments are required to improve the water quality of the recent condition in the Kelantan River.

\section{CONCLUSIONS}

Clean freshwater is the most crucial thing for daily human activities. Since the Kelantan River is the largest river in Peninsular Malaysia, therefore, it becomes important to maintain the water quality of the Kelantan River. The increase of development activities and land use 
changes in Kelantan city from year 2012 to 2018 (in example, 1,729 \% for construction and $22 \%$ for cropland), have declined the water quality in downstream of Kelantan River, Peninsular Malaysia. The obtained results from this study demonstrated that extensive treatment of river water is required in order to improve the water quality for water supply. The better strategies are also required in controlling the quality of freshwater in the Kelantan River as well as minimize the occurrence of pollution problems.

\section{ACKNOWLEDGEMENT}

The authors would like to sincerely thank Universiti Kebangsaan Malaysia (UKM) for providing funds to support in completing this study (research grant DIP-2018-030). The authors also gratefully acknowledge the Earth Observation Centre, Institute of Climate Changes, UKM and Universitas Teknokrat Indonesia for supporting data and spirit while completing this study.

\section{REFERENCES}

Abdul Maulud, K. N., Fitri, A., Wan Mohtar, W. H. M., Wan Mohd Jaafar, W.S., Zuhairi, N.Z., Kamarudin, M. K. . (2020). A Study of Spatial and Water Quality Index During dry and rainy seasons at Kelantan River Basin, Peninsular Malaysia. Arabian Journal of Geosciences (Accepted, 14th December 2020).

Afroz, R., Masud, M. M., Akhtar, R., \& Duasa, J. B. (2014). Water pollution: Challenges and future direction for water resource management policies in malaysia. Environment and Urbanization ASIA. https://doi.org/10.1177/0975425314521544

Ahmad, A. K., Mushrifah, I., \& Shuhaimi-Othman, M. (2009). Water quality and heavy metal concentrations in sediment of Sungai Kelantan, Kelantan, Malaysia: A baseline study. Sains Malaysiana.

Amneera, W. A., Najib, N. W. A. Z., Mohd Yusof, S. R., \& Ragunathan, S. (2013). Water quality index of Perlis River, Malaysia. International Journal of Civil \& Environmental Engineering.

APHA. (2017). Standard Methods for examination of water and wastewater. In American Public Health Association (APHA).

Camara, M., Jamil, N. R., \& Abdullah, A. F. Bin. (2019). Impact of land uses on water quality in Malaysia: a review. In Ecological Processes. https://doi.org/10.1186/s13717-019-0164-x

Chapman, D. (1996). Groundwater Pollution - Developments in Water Science. Water Quality Assessments - A Guide to Use of Biota, Sediments and Water in Environmental Monitoring Second Edition Edited.

Department of Environment. (2014). Malaysia Environmental Quality Report. Department of Environment, Malaysia.

Fulazzaky, M. A., Seong, T. W., \& Masirin, M. I. M. (2010). Assessment of water quality status for the selangor river in Malaysia. Water, Air, and Soil Pollution. https://doi.org/10.1007/s11270009-0056-2

HACH, C. (2007). DR 2800 Spectrophotometer User Manual. Hach Company.

Hee, Y. Y., Suratman, S., \& Aziz, A. A. (2019). Water Quality and Heavy Metals Distribution in Surface Water of the Kelantan River Basin (Malaysia). Oriental Journal Of Chemistry. https://doi.org/10.13005/ojc/350402

Juahir, H., Zain, S. M., Yusoff, M. K., Hanidza, T. I. T., Armi, A. S. M., Toriman, M. E., \& Mokhtar, M. (2011). Spatial water quality assessment of Langat River Basin (Malaysia) using environmetric techniques. Environmental Monitoring and Assessment. https://doi.org/10.1007/s10661-010-1411-x

Kamarudin, M. K. A., Nalado, A. M., Toriman, M. E., Juahir, H., Umar, R., Ismail, A., Abd Wahab, N., Md Saad, M. H., Maulud, K. N., Hanafiah, M. M., Mohd Saudi, A. S., \& Harith, H. (2019). Evolution of river geomorphology to water quality impact using remotesensing and GIS technique. Desalination and Water Treatment. https://doi.org/10.5004/dwt.2019.23838 
Lai, S. H., \& Fitri, A. (2011). Application of SWAT Hydrological Model to Upper Bernam River Basin (UBRB), Malaysia. IUP Journal of Environmental Sciences, 5(2).

Ma'arof, N., \& Hua, A. K. (2015). Kualiti air Sungai UTM : Satu penilaian awal berpandukan enam parameter Indeks Kualiti Air. Kualiti Air Sungai UTM : Satu Penilaian Awal Berpandukan Enam Parameter Indeks Kualiti Air.

Mokhtar, M. Bin, Aris, A. Z., Abdullah, M. H., Yusoff, M. K., Abdullah, M. P., Idris, A. R., \& Raja Uzir, R. I. (2009). A pristine environment and water quality in perspective: Maliau Basin, Borneo's mysterious world. Water and Environment Journal. https://doi.org/10.1111/j.17476593.2008.00139.x

Peck Yen, T., \& Rohasliney, H. (2013). Status of water quality subject to sand mining in the Kelantan River, Kelantan. Tropical Life Sciences Research.

Suratman, S., Awang, M., Ling, L. A., \& Tahir, N. M. (2009). Kajian indeks kualiti air di lembangan Sungai Paka, Terengganu. Sains Malaysiana.

Varol, M. (2020). Spatio-temporal changes in surface water quality and sediment phosphorus content of a large reservoir in Turkey. Environmental Pollution. https://doi.org/10.1016/j.envpol.2019.113860

Wahab, N. A., Amri Kamarudin, M. K., Toriman, M. E., Juahir, H., Md Saad, M. H., Ata, F. M., Ghazali, A., Hassan, A. R., Abdullah, H., Maulud, K. N., Hanafiah, M. M., \& Harith, H. (2019). Sedimentation and water quality deterioration problems at Terengganu Riverbasin, Terengganu, Malaysia. Desalination and Water Treatment. https://doi.org/10.5004/dwt.2019.23836

Wu, Z., Wang, X., Chen, Y., Cai, Y., \& Deng, J. (2018). Assessing river water quality using water quality index in Lake Taihu Basin, China. Science of the Total Environment. https://doi.org/10.1016/j.scitotenv.2017.08.293 